\title{
DIREITOS FUNDAMENTAIS DOS TRABALHADORES: DIREITO SUBJETIVO DE INDENIZAÇÃO POR DANOS MORAIS AOS FAMILIARES DE VÍTIMA DE ACIDENTE DO TRABALHO
}

\author{
Rodrigo Rebello Campos ${ }^{99}$
}

Recebido em: 10/08/2018

Aprovado em: 02/10/2018

\begin{abstract}
RESUMO
$\mathrm{O}$ artigo explora acerca dos aspectos jurídicos do direito de percepção de indenização extrapatrimonial decorrente de acidente de trabalho com óbito. O objetivo é mapear e analisar se a indenização por danos morais já percebida por meio de transação, conciliação ou sentença judicial pelos herdeiros (viúva e filhos) do empregado vítima de acidente de trabalho, criam óbice à abertura de nova demanda pelos demais familiares (pais e irmãos) na busca da mesma indenização, em exercício do direito subjetivo contido na Constituição Federal de 1988. Quanto ao problema de pesquisa, será descrever sobre a possibilidade de percepção de indenização por danos morais em sucessivas ações, por inúmeras pessoas, ligadas da mesma forma ao vínculo afetivo do ofendido por meio de nova transação, conciliação ou sentença judicial? A hipótese apresentada refere-se à possibilidade de percepção de indenização por danos morais para todos os membros adstritos ao núcleo familiar do empregado, podendo coexistir várias demandas judiciais oriundas do mesmo fato. A pesquisa científica terá metodologia da seguinte forma: pura, qualitativa, exploratória, descritiva e bibliográfica, com a análise de legislação, artigos científicos, obras jurídicas e material disponibilizado na Internet.
\end{abstract}

Palavras-chave: Direitos fundamentais. Responsabilidade civil do empregador. Acidentes do trabalho. Meios legais de solução de conflitos trabalhistas. Indenização por danos morais.

\section{INTRODUÇÃO}

No Brasil, o direito do trabalho preocupa-se precipuamente em tutelar as relações de emprego, concebendo mecanismos jurídicos de regulação do trabalho subordinado. Desse modo, todos os empregados enquadrados nesta relação jurídica nuclear terão garantidos os seus direitos legais, respeitando-se o mínimo existencial para a sua sobrevivência, em

\footnotetext{
${ }^{99}$ Mestrando em Direito pela Universidade Federal de Mato Grosso do Sul - UFMS.
} 
atendimento aos princípios fundamentais do Estado Democrático de Direito, tais como: a dignidade humana, a livre iniciativa e a valorização do trabalho humano.

Muito embora a grande maioria dos estados modernos ratifiquem legislação própria referente ao trabalho e ao processo do trabalho, a aplicação de mecanismos extrajudiciais para a solução de conflitos trabalhistas ainda é tímida, principalmente nos países de tradição romano-germânica como o Brasil, ao qual os cidadãos adotam preferencialmente o modelo judicial para resolução de seus conflitos, tendo-se em vista maior alusão as normas jurídicas positivadas (LIMA, 2013, p. 82).

Não há dúvida de que as relações de trabalho, em sentido amplo, contribuem para a ascensão social do indivíduo, elevando-o ao patamar de ator social participativo junto à ordem econômica de seu país, bem como, de consumidor e participante ativo na vida política de seu Estado, porém, as relações de trabalho na atualidade brasileira refletem cada vez mais a adequação à ordem econômica globalizada, consumista e cada vez menos humanista, limitando o empregado ao seu ser-econômico, logo, a pacificação social deve ser incentivada pelo Estado Democrático de Direito (WENCESLAU; SANTOS, 2016, pg. 173).

Destarte, em que pese tais considerações preliminares acerca do trabalho contemporâneo, o estudo sob enfoque procura abordar aspectos jurídicos referentes a relação de trabalho subordinado e aos meios legais de solução de conflitos, face as implicações jurídicas do direito subjetivo de indenização por danos morais no caso de morte do trabalhador em acidente do trabalho.

Por sua vez, no caso de falecimento de trabalhador em acidente do trabalho, a competência material para julgar e processar as lides oriundas da relação de emprego é da justiça do trabalho conforme alude o art. 114, I e VI, da CF (BRASIL, 1988) ${ }^{100}$, neste sentido aduz Farias (2015, pg. 107):

É sabido que o controle estatal das relações de trabalho no Brasil é feito principalmente pela união federal. Para tanto, em cada uma de suas esferas e atribuições legais, existe a justiça do trabalho, o ministério público do trabalho e mesmo a cooperação eventual da polícia federal.

Como será adiante demonstrado, a Lei Civil e o Novo Código de Processo Civil são aplicáveis ao processo do trabalho com base nos arts. 8 e 769, da CLT (BRASIL, 1943) ${ }^{101}$.

\footnotetext{
100 Art. 114. Compete à Justiça do Trabalho processar e julgar: I - as ações oriundas da relação de trabalho, abrangidos os entes de direito público externo e da administração pública direta e indireta da União, dos Estados, do Distrito Federal e dos Municípios; VI - as ações de indenização por dano moral ou patrimonial, decorrentes da relação de trabalho;

${ }^{101}$ Art. $8^{\circ}$ - As autoridades administrativas e a Justiça do Trabalho, na falta de disposições legais ou contratuais, decidirão, conforme o caso, pela jurisprudência, por analogia, por equidade e outros princípios e normas gerais
} 
A aplicação dessas normas legais na omissão da famigerada CLT, tem o objetivo de melhorar a adequação material e processual de institutos jurídicos análogos do direito comum ao direito do trabalho, diante dos novos anseios da sociedade, possibilitando o exercício dos direitos fundamentais dos trabalhadores.

Desse modo, o estudo será descritivo analítico, para mapear e analisar sobre o exercício do direito de ação de indenização por danos morais no âmbito dos processos judiciais do trabalho, diante da aplicação dos mecanismos legais de solução de conflitos nos dissídios individuais trabalhistas em confronto com o interesse processual dos familiares da vítima de acidente de trabalho, motivados pela dor da perda do ente querido com base no art. 5, V e X da CF (BRASIL, 1988) ${ }^{102}$.

Assim, busca-se analisar se a indenização por danos morais já percebida por meio de transação, conciliação ou sentença judicial pelos herdeiros (viúva e filhos) do empregado vítima de acidente de trabalho, criam óbice à abertura de nova demanda pelos demais familiares (pais e irmãos) na busca da mesma indenização, em exercício do direito subjetivo contido na Constituição Federal de 1988.

Portanto, o problema de pesquisa será descrever sobre a possibilidade de percepção de indenização por danos morais em sucessivas ações, por inúmeras pessoas, ligadas da mesma forma ao vínculo afetivo do ofendido por meio nova transação, conciliação ou sentença judicial.

A hipótese apresentada refere-se à possibilidade de percepção de indenização por danos morais para todos os membros adstritos ao núcleo familiar do empregado, podendo coexistir várias demandas judiciais oriundas do mesmo fato.

Dessa forma, a pesquisa vai analisar se a transação, conciliação e a sentença judicial poderão provocar óbice ao direito de percepção de indenização por todos aqueles familiares ligados de certa forma ao vínculo afetivo do ofendido, que suportam o dano e sofrem com a perda do ente querido vitimado em acidente de trabalho.

de direito, principalmente do direito do trabalho, e, ainda, de acordo com os usos e costumes, o direito comparado, mas sempre de maneira que nenhum interesse de classe ou particular prevaleça sobre o interesse público. $\S 1^{\circ}$ - O direito comum será fonte subsidiária do direito do trabalho. Art. 769 - Nos casos omissos, o direito processual comum será fonte subsidiária do direito processual do trabalho, exceto naquilo em que for incompatível com as normas deste Título.

102 Art. $5^{\circ}$ Todos são iguais perante a lei, sem distinção de qualquer natureza, garantindo-se aos brasileiros e aos estrangeiros residentes no País a inviolabilidade do direito à vida, à liberdade, à igualdade, à segurança e à propriedade, nos termos seguintes: V - é assegurado o direito de resposta, proporcional ao agravo, além da indenização por dano material, moral ou à imagem; $X$ - são invioláveis a intimidade, a vida privada, a honra e a imagem das pessoas, assegurado o direito a indenização pelo dano material ou moral decorrente de sua violação; 
De fato, o interesse pela elaboração desse estudo é o direito fundamental de indenização, acesso à justiça, segurança jurídica e à pacificação social dos conflitos, paradigmas do Estado Democrático de Direito, já que havendo várias demandas judiciais oriundas do mesmo fato, poderá acarretar certa instabilidade jurídica e morosidade processual.

O tema merece ser examinado em razão destas questões ainda não muito claras entre os teóricos e a legislação nacional. Acerca dos aspectos metodológicos, a pesquisa adotada será pura, qualitativa, exploratória, descritiva e bibliográfica, elaborada a partir de material já publicado, constituído de doutrina, legislação, material disponibilizado na Internet e artigos científicos (SEVERINO, 2007, p. 119).

No primeiro subtítulo será abordado acerca dos direitos fundamentais dos trabalhadores e a responsabilidade civil do empregador face ao direito subjetivo de indenização por acidente de trabalho. Mais adiante será apresentado aspectos sobre a transação, conciliação e a sentença judicial como mecanismos de solução dos conflitos trabalhistas e os danos extrapatrimoniais em acidentes do trabalho com vítima fatal.

Mormente, os mecanismos de autocomposição sem dúvida promovem a solução dos conflitos trabalhistas de forma mais célere e efetiva em termos de satisfação das partes, cabendo apenas delimitar os sujeitos desta relação e a amplitude dos efeitos desta disposição de direitos como método eficaz de pacificação social.

\section{DIREITOS FUNDAMENTAIS E A RESPONSABILIDADE CIVIL DO EMPREGADOR: DIREITO SUBJETIVO DE INDENIZAÇÃO POR DANO MORAL DECORRENTE DE ACIDENTES DO TRABALHO}

Quanto aos acidentes do trabalho, em que pese haver crescente conscientização e ações criadas em consonância com a Política Nacional de Segurança e Saúde no Trabalho, instituída pelo Decreto n 7.602 (BRASIL, 2011), os acidentes laborais continuam ocorrendo no Brasil.

Numa análise constitucional, após a sua promulgação em 1988, vislumbrou-se significativo avanço acerca da proteção do meio ambiente de trabalho e a responsabilidade civil do empregador por danos acidentários, devido a positivação de princípios voltados à preservação da dignidade humana para a valorização do trabalho frente à ordem econômica do país, instituindo-se direitos fundamentais dos trabalhadores urbanos e rurais (OLIVEIRA, 1988, pg. 31-32). 
Pode-se conceituar os direitos fundamentais, como aqueles direitos jurídicos positivados e vigentes numa ordem jurídica constitucional, expressos ou implícitos, institucionalmente garantidos e limitados no espaço temporalmente (CANOTILHO, 2003, pg. 130-132).

Nota-se que os direitos fundamentais são espécies do gênero direito subjetivo, pois os direitos subjetivos depois de positivados pelo ordenamento jurídico interno, tornam-se válidos e geram efeitos jurídicos, já que os direitos fundamentais são em sua maioria de cunho individual, civil e político.

O direito subjetivo à indenização por dano moral e material são direitos fundamentais, expressos junto ao art. 5, V e $\mathrm{X}^{103}$, da CF (BRASIL, 1988), decorrentes da ofensa direta dos direitos de personalidade do indivíduo, mormente, à proteção dos direitos dessa natureza ganharam destaque após a vinda do Novo Código Civil, que tratou de exemplifica-los junto aos arts. 11 a 21, do CC (BRASIL, 2002).

Corrente teórica defende a existência de uma cláusula aberta não taxativa sobre o conceito de dano moral (CASSETTARI, 2015, pg. 276-279). Assim, a proteção ao meio do trabalho está umbilicalmente ligada a dignidade da pessoa humana, pois ambos os princípios positivados tratam-se de normas de direito fundamental expressos na Constituição Federal junto ao art. 7, XXII, XXIII e XXVIII, da CF (BRASIL, 1988), sem deixar de lado o importante tripé axiológico da dignidade humana, valorização do trabalho e da livre iniciativa, ambos de nítido interesse social, conforme art. 1, III, IV, da CF (BRASIL, 1988).

Preservar o meio ambiente de trabalho é de fundamental importância para a manutenção da saúde, higiene e segurança de todos os indivíduos que lá interagem habitualmente. Desse modo, o Legislador Constituinte preocupado com o bem-estar dos trabalhadores, positivou princípios específicos que enaltecem a dignidade humana, estes que visam à proteção do meio ambiente do trabalho e a redução de acidentes.

Portanto, as garantias fundamentais e os princípios voltados para a proteção do meio ambiente do trabalho presentes na Constituição Federal, além do caráter normativo, orientam o legislador infraconstitucional a criar por meio da legislação ordinária, mecanismos legais para a redução dos riscos de acidentes do trabalho, estando esses direitos fundamentais positivados na matriz constitucional (SARLET, 2006, p. 29).

\footnotetext{
${ }^{103}$ Art. $5^{\circ}$, CF. Todos são iguais perante a lei, sem distinção de qualquer natureza, garantindo-se aos brasileiros e aos estrangeiros residentes no País a inviolabilidade do direito à vida, à liberdade, à igualdade, à segurança e à propriedade, nos termos seguintes: V - é assegurado o direito de resposta, proporcional ao agravo, além da indenização por dano material, moral ou à imagem; $X$ - são invioláveis a intimidade, a vida privada, a honra e a imagem das pessoas, assegurado o direito a indenização pelo dano material ou moral decorrente de sua violação;
} 
Quanto a responsabilização civil do empregador pelos danos decorrentes de acidentes do trabalho, o art. $7^{\circ}$, XXVIII, da CF (BRASIL, 1988) regula de forma binária o modo de reparação dos danos acidentários no ordenamento jurídico brasileiro, ou seja, conjugou duplo espectro de assistência ao trabalhador vitimado por alguma infortunística laboral, conforme destaca o teórico abaixo:

A legislação brasileira adota um sistema binário de reparação dos prejuízos decorrentes de acidentes do trabalho: o da seguridade social, como garantia inafastável do trabalhador e, eventualmente, o da responsabilidade civil do empregador. Diz-se "eventualmente" não com conotação de esporadicidade, mas sim para de destacar que a responsabilização civil do empregador ocorrerá apenas quando presentes determinados "eventos" ou "situações". (PINTO JUNIOR, 2016, p. 36).

Assim, a responsabilidade civil do empregador será subjetiva na esfera judicial em aplicação do princípio da reparação integral, por meio de indenização acessória de danos ou de reparação aos direitos de personalidade aplicado subsidiariamente ao direito do trabalho nos termos do Código Civil (BRASIL, 2002).

O art. $19^{\circ}$, da Lei $n^{\circ} .8 .213$ (BRASIL, 1991) ${ }^{104}$ consagra o conceito de "acidente tipo" ou acidente típico que é o acidente que ocorre a serviço da empresa ou do empregador doméstico, provocando lesão corporal ou funcional que cause a morte ou incapacidade temporária ou definitiva para o trabalho.

Porém, em que pese a Lei Maior positivar a responsabilidade civil subjetiva do empregador junto ao art. $7^{\circ}$, XXVIII, da CF (BRASIL, 1988), tal norma não impede a aplicação da responsabilidade civil objetiva com base na teoria do risco em algumas situações e eventos, já que o art. $7^{\circ}$, caput, da CF (BRASIL, 1988) permite a aplicação de outros direitos que visem à melhoria da condição social do trabalhador, vedando expressamente o retrocesso social, nesse sentido acerca da teoria do risco e a degradação do meio ambiente do trabalho:

Não obstante a controvérsia, ainda atual, acerca da natureza da responsabilidade
civil do empregador por danos acidentários relacionados ao trabalho, em face do que
dispõe o próprio texto constitucional sobre o tema, o dissídio nem sequer se
justificaria. Isso porque, segundo prevê o caput do art. 255 da Constituição Federal,
todos têm o direito ao meio ambiente ecologicamente equilibrado, cuja violação,
conforme garante a norma do $\$ 3^{\circ}$ do dispositivo mencionado, ensejará
responsabilização penal e administrativa dos infratores, "independentemente da
obrigação de reparar os danos causados". A responsabilidade sem culpa, nesse caso,
é inferida do fato de o preceito nada exigir acerca do elemento subjetivo na conduta,

104 Art. 19. Acidente do trabalho é o que ocorre pelo exercício do trabalho a serviço de empresa ou de empregador doméstico ou pelo exercício do trabalho dos segurados referidos no inciso VII do art. 11 desta Lei, provocando lesão corporal ou perturbação funcional que cause a morte ou a perda ou redução, permanente ou temporária, da capacidade para o trabalho. 
daí por que, se a constituição não restringe, não o pode fazer o interprete. (PINTO JUNIOR, 2016, pg. 71).

Destaca-se que o acidente de trabalho em algumas situações impõe ao empregador responsabilidades extracontratuais para com as vítimas ou seus dependentes e sucessores, caso seja apurada a sua responsabilidade civil no que diz respeito a indenização dos prejuízos patrimoniais e extrapatrimoniais dos prejudicados, excluído o benefício previdenciário correspondente que é de competência da seguridade social.

\section{MEIOS LEGAIS DE SOLUÇÃO DE CONFLITOS TRABALHISTAS: DANOS EXTRAPATRIMONIAIS DECORRENTES DE ACIDENTES DE TRABALHO COM VÍTIMA FATAL}

Discorrido acerca da existência do direito fundamental de proteção ao meio ambiente do trabalho, do direito subjetivo de indenização e a responsabilidade civil do empregador, cumpre agora mapear e analisar se a indenização por danos morais já percebida por meio de transação, conciliação ou sentença judicial pelos herdeiros (viúva e filhos) do empregado vítima de acidente de trabalho, criam óbice à abertura de nova demanda pelos demais familiares (pais e irmãos) na busca da mesma indenização, em exercício do direito subjetivo contido na Constituição Federal de 1988.

No que concerne ao âmbito laborativo em sentido estrito, os acidentes do trabalho consubstanciam séria oneração ao empregador e consequentemente a toda à sociedade, atingindo diretamente os direitos patrimoniais e extrapatrimoniais do ofendido (OLIVEIRA, 2013, p. 31-33), esta é a dificuldade de se efetivar com eficiência a aproximação das partes para a autocomposição em processos judiciais.

Com a vigência do Novo Código de Processo Civil de aplicação subsidiária ao processo do trabalho, a autocomposição foi estimulada pelo legislador, assim, foi instituída a audiência inicial de conciliação ou de mediação, cabendo ao autor na petição inicial consignar o interesse ou não nessa audiência e o réu, em manifestação anterior a apresentação da contestação, conforme preconiza o art. 334, do CPC (BRASIL, 2015) ${ }^{105}$.

Ocorre, que corrente teórica defendeu a inaplicabilidade de tal dispositivo ao Processo do Trabalho, tendo em vista a existência de inúmeras aspectos que dificultam a realização da

${ }^{105}$ Art. 334, CPC. Se a petição inicial preencher os requisitos essenciais e não for o caso de improcedência liminar do pedido, o juiz designará audiência de conciliação ou de mediação com antecedência mínima de 30 (trinta) dias, devendo ser citado o réu com pelo menos 20 (vinte) dias de antecedência. 
mediação nos dissídios individuais, desde a ausência de estrutura da Justiça do Trabalho para a realização das audiências, bem como, pelo fato da audiência ser realizada por conciliadores ou mediadores, afastando a figura do juiz togado, o que atentaria contra os princípios da proteção e da indisponibilidade de direitos (SOUTO MAIOR, 2015, pg. 34-40).

Quanto às verbas trabalhistas próprias decorrentes do emprego, a renúncia de direitos só é permitida depois de encerrada a relação jurídica entabulada entre as partes, já que os direitos trabalhistas são irrenunciáveis na vigência do contrato de trabalho, podendo haver autocomposição em juízo com a assistência do magistrado que irá verificar acerca da inexistência de fraude (MARTINS, 2018, p. 61-65).

Do mesmo modo, a autocomposição das demais verbas trabalhistas conexas ao contrato de trabalho, poderá ser efetivada com a assistência do juiz do trabalho, já que tais verbas possuem natureza jurídica indenizatória quando decorrentes de acidentes do trabalho, assim, a conciliação ou a transação de direitos consubstanciam fortes instrumentos jurídicos para a solução consensual dos conflitos postos em juízo pelas partes (CALMON, 2008, p. 53).

Porém, há dificuldade para as partes em estabelecer valores e delimitar os legitimados a receber tais verbas em transação ou conciliação, ainda mais quando existe a possibilidade de exclusão de tal responsabilidade patronal em juízo, ou mesmo necessidade do exercício do ônus de prova da culpa empresarial pelo autor da ação (PINTO JUNIOR, 2016, p. 59-66).

Ademais, na transação judicial sem a intermediação direta do magistrado em audiência, ao qual é submetido o pedido de composição ao juízo trabalhista para homologação, podem as partes optar pela quitação total dos direitos decorrentes do extinto contrato de trabalho com base no art. 515, II, § 2, do CPC (BRASIL, 2015) ${ }^{106}$, pedido que será apreciada pelo magistrado competente, diante da indisponibilidade de algumas parcelas obreiras e também diante da natureza obrigatória de fixação das contribuições sociais nos termos do art. 22, da Lei n. 8.212 (BRASIL, 1991) ${ }^{107}$.

Os teóricos há muito tempo diferenciam a conciliação da transação. Tais mecanismos de solução de conflitos parecem se assemelhar em alguns aspectos, contudo, possuem

\footnotetext{
106 Art. 515. São títulos executivos judiciais, cujo cumprimento dar-se-á de acordo com os artigos previstos neste Título: II - a decisão homologatória de autocomposição judicial; § 2. A autocomposição judicial pode envolver sujeito estranho ao processo e versar sobre relação jurídica que não tenha sido deduzida em juízo.

${ }^{107}$ Art. 22. A contribuição a cargo da empresa, destinada à Seguridade Social, além do disposto no art. 23, é de: I - vinte por cento sobre o total das remunerações pagas, devidas ou creditadas a qualquer título, durante o mês, aos segurados empregados e trabalhadores avulsos que lhe prestem serviços, destinadas a retribuir o trabalho, qualquer que seja a sua forma, inclusive as gorjetas, os ganhos habituais sob a forma de utilidades e os adiantamentos decorrentes de reajuste salarial, quer pelos serviços efetivamente prestados, quer pelo tempo à disposição do empregador ou tomador de serviços, nos termos da lei ou do contrato ou, ainda, de convenção ou acordo coletivo de trabalho ou sentença normativa.
} 
distintos conceitos e também apresentam certas particularidades próprias. Na conciliação as partes contam com a ajuda de um terceiro imparcial, dotado de conhecimento técnico e jurídico, que poderá incentivar as partes a uma composição amigável, já a transação é realizada pelas próprias partes sem a intermediação de terceiro (CALMON DE PASSOS, 2001, p. 450-452).

$\mathrm{Na}$ conciliação realizada depois de encerrado o vínculo de emprego, o elemento fático jurídico da subordinação do empregado ao empregador de certa forma estará mais flexível, podendo o mesmo dispor de seus direitos patrimoniais em juízo, não podendo o conciliador impor sua vontade, agindo somente para incentivar a composição amigável por meio de propostas legítimas e recomendáveis para a solução do conflito (SENA, 2007, p. 153-154).

Ademais, será de suma importância para a validade da conciliação e da transação, que tais mecanismos sejam realizados por pessoas legitimadas por lei a receber todos os direitos decorrentes da extinta relação de emprego no caso de acidente fatal no trabalho, afim de se evitar irregularidades processuais.

As verbas trabalhistas são identificadas por sua natureza jurídica, desse modo, quanto às verbas rescisórias, salariais, remuneratórias e indenizatórias típicas ou próprias do contrato de trabalho, na hipótese de extinção contratual em razão de falecimento do empregado por acidente de trabalho, podem as partes transacionar ou conciliar acerca das verbas patrimoniais e receberem as demais de titularidade do empregado vitimado no acidente (DALLGRAVE NETO, 2014, p. 488-494), que serão pagos ao espólio ou aos familiares legitimados por meio de alvará judicial expedido junto à justiça comum estadual caso inexistente a certidão de habilitação sucessória expedida pela Previdência Social, diante do permissivo legal contido no art. 1, da lei n. 6.858 (BRASIL, 1980) ${ }^{108}$

A autocomposição das demais verbas indenizatórias conexas ao contrato de trabalho poderão ser de natureza jurídica extracontratual, caso decorrentes de acidentes do trabalho. Nesta categoria, não haverá óbice a propositura de ação trabalhista para apuração de eventuais verbas indenizatórias diante da afronta aos direitos de personalidade e a faculdade de exercício do direito de ação nos termos do art. 5, V e X, da CF (BRASIL, 1988).

Nas relações de emprego a utilização de métodos alternativos de solução de conflitos no transcurso do contrato de trabalho pode se dar pela via extrajudicial, sujeitos a revisão

\footnotetext{
108 Art. $1^{\text {o }}$ - Os valores devidos pelos empregadores aos empregados e os montantes das contas individuais do Fundo de Garantia do Tempo de Serviço e do Fundo de Participação PIS-PASEP, não recebidos em vida pelos respectivos titulares, serão pagos, em quotas iguais, aos dependentes habilitados perante a Previdência Social ou na forma da legislação específica dos servidores civis e militares, e, na sua falta, aos sucessores previstos na lei civil, indicados em alvará judicial, independentemente de inventário ou arrolamento.
} 
judicial, diante do desiquilíbrio econômico existente entre as partes e a opção do empregado em algumas hipóteses, de não discutir a relação contratual antes do término do vínculo laboral, em garantia de uma suposta permanência no emprego ou diante do caráter irrenunciável de certas parcelas obreiras.

Por outro lado, a autocomposição é muito utilizada nas extinções contratuais. As associações sindicais cumprem importante papel ao homologar e criar ressalvas quanto aos direitos trabalhistas quitados pelos empregadores aos seus empregados, quando extinto o antigo contrato de trabalho, especificando a natureza de cada parcela paga ao empregado conforme dispõe o art. 447, $\S 2^{\circ}$, da CLT (BRASIL, 1943) ${ }^{109}$.

Mormente, havendo divergência quanto aos valores quitados, não há óbice legal para o ajuizamento de ação trabalhista para se apurar eventuais diferenças de valores, podendo-se afirmar que a transação extrajudicial não tem o condão de declarar a quitação total dos direitos conquistados na extinta relação de emprego, diante de expressa previsão legal extraída do dispositivo celetista acima mencionado.

Existe outro mecanismo de autocomposição de conflitos trabalhistas além da transação e da conciliação, a legislação trabalhista prevê a existência da Comissão de Conciliação Prévia, que tem o escopo de solucionar eventuais divergências existentes entre as partes antes de qualquer medida judicial, esta que pode ser criada no âmbito intersindical ou empresarial com base no art. 625-A, da CLT (BRASIL, 1943) ${ }^{110}$.

Utilizada a Comissão, as partes podem transacionar direitos com eficácia parcial de quitação, ou seja, as verbas consignadas no termo conciliatório não mais poderão ser discutidas, limitando o exercício do direito de ação obreira as verbas não expressas na transação, tendo-se em vista que a utilização da comissão é uma faculdade das partes, conforme art. 625-E, da CLT (BRASIL, 1943) ${ }^{111}$.

\footnotetext{
109 Art. 477. Na extinção do contrato de trabalho, o empregador deverá proceder à anotação na Carteira de Trabalho e Previdência Social, comunicar a dispensa aos órgãos competentes e realizar o pagamento das verbas rescisórias no prazo e na forma estabelecidos neste artigo. $\S 2^{\circ}$ - O instrumento de rescisão ou recibo de quitação, qualquer que seja a causa ou forma de dissolução do contrato, deve ter especificada a natureza de cada parcela paga ao empregado e discriminado o seu valor, sendo válida a quitação, apenas, relativamente às mesmas parcelas.

${ }^{110}$ Art. 625-A. As empresas e os sindicatos podem instituir Comissões de Conciliação Prévia, de composição paritária, com representante dos empregados e dos empregadores, com a atribuição de tentar conciliar os conflitos individuais do trabalho. Parágrafo único. As Comissões referidas no caput deste artigo poderão ser constituídas por grupos de empresas ou ter caráter intersindical.

111 Art. 625-E. Aceita a conciliação, será lavrado termo assinado pelo empregado, pelo empregador ou seu proposto e pelos membros da Comissão, fornecendo-se cópia às partes. Parágrafo único. O termo de conciliação é título executivo extrajudicial e terá eficácia liberatória geral, exceto quanto às parcelas expressamente ressalvadas.
} 
Tratando-se de verbas conexas ao contrato de trabalho decorrentes de acidentes do trabalho, mesmo que submetidas ao instituto jurídico da responsabilidade civil extracontratual para apuração dos pressupostos legais de indenização, não há óbice legal para a efetivação de transação extrajudicial junto à Comissão de Conciliação Prévia (SUSSEKIND, 2000, p. 1.316).

Ademais, as partes podem optar pela transação judicial após a prolação de eventual sentença condenatória que fixará a responsabilidade civil patronal, medida que parece ser mais adequada em cumprimento do princípio da reparação integral, já que havendo excludente ou isenção de responsabilidade civil, não há falar em indenização aos danos extracontratuais, conforme art. 764, $\S 3^{\circ}$ da CLT (BRASIL, 1943) $)^{112}$.

Cabe agora examinar quais os efeitos da transação e da conciliação nos dissídios individuais trabalhistas e os seus limites no caso de obreiro vitimado em acidente de trabalho. Tratam-se de questões de inestimável importância para a resolução do problema proposto neste trabalho.

Não raro, em algumas situações a legitimidade para a causa pode ser conferida a terceiro de forma extraordinária, contudo, a principal modalidade observada nos dissídios individuais é a legitimidade ordinária. A legitimidade para a causa está ligada diretamente com aquele que detém a faculdade de postular certa pretensão em face de outrem, quando violado ou frustrado o exercício de certo direito (DINAMARCO, 2001, p. 303).

Tratando-se de acidente de trabalho com morte do empregado, a legitimidade para postular indenização por dano material é conferida aos familiares da vítima no caso de responsabilidade civil ${ }^{113}$, logo, poderão ajuizar em nome próprio ação indenizatória como titulares do direito subjetivo atacado, em razão do acidente ocorrido no local de trabalho (PINTO JUNIOR, 2016, pg. 120-121).

Esta modalidade de pretensão para processar e julgar a ação trabalhista indenizatória é de competência material da justiça do trabalho, assim, a transação ou a conciliação que versar sobre direitos patrimoniais diante do falecimento de obreiro em acidente de trabalho observará o contido no art. 948, do CC (BRASIL, 2002) $)^{114}$.

\footnotetext{
${ }^{112}$ Art. 764 - Os dissídios individuais ou coletivos submetidos à apreciação da Justiça do Trabalho serão sempre sujeitos à conciliação. $\S 3^{\circ}$ - É lícito às partes celebrar acordo que ponha termo ao processo, ainda mesmo depois de encerrado o juízo conciliatório.

113 Trata-se da ação de indenização por danos morais e materiais de competência da justiça do trabalho e não da ação de concessão do benefício previdenciário acidentário que é de competência da justiça comum estadual conforme art. 109, I, da CRFB/88.

${ }^{114}$ Art. 948. No caso de homicídio, a indenização consiste, sem excluir outras reparações: I - no pagamento das despesas com o tratamento da vítima, seu funeral e o luto da família; II - na prestação de alimentos às pessoas a quem o morto os devia, levando-se em conta a duração provável da vida da vítima.
} 
Por outro lado, diferentemente do dano patrimonial, tratando-se de danos extrapatrimoniais decorrentes de acidentes do trabalho com óbito, qualquer pessoa ligada ao círculo afetivo do de cujus poderá ajuizar ação indenizatória em nome próprio, sob a alegação de lesão aos seus direitos de personalidade, ou seja, o direito de ação será de todos aqueles que mantinham de certa forma laços de afeto com o falecido (DALLEGRAVE NETO, 2014, pg. 488-489).

Não obstante, em algumas situações por motivos variados, nem sempre todos os familiares da vítima de acidente de trabalho figuram no polo ativo de uma ação judicial desta natureza, por se tratar de um direito subjetivo face à lesão aos direitos de personalidade, podendo ser ajuizada nova demanda, ao qual o juízo deverá instigar as partes a autocomposição, conforme reza o art. 139, V, do CPC (BRASIL, 2015) e o art.764, da CLT $(\text { BRASIL, 1943) })^{115}$.

Diante da abrangência da norma contida no art. 5, V e X, da CF (BRASIL, 1988), corrente teórica firmou entendimento de que é possível a percepção de indenização por danos morais em sucessivas ações, por inúmeras pessoas, ligadas da mesma forma ao vínculo afetivo do ofendido, seja por meio de nova transação, conciliação ou sentença judicial, porém, o dano moral será presumido aos familiares próximos da vítima, quanto aos demais que fogem do círculo familiar afetivo, o dano deverá ser cabalmente provado (DIAS, 1954, p. 782).

Neste sentido, Oliveira (2013, p. 281) destaca:

Na hipótese, os familiares, dependentes ou os que se sentirem de algum modo lesados poderão intentar ação jure proprio, para obter a reparação do dano moral. Não agirão na condição de sucessores da vítima, mas como autores, em nome próprio, buscando a indenização cabível.

Corrente teórica contrária, firmou entendimento que o ajuizamento de ação de indenização por danos morais em virtude de acidente de trabalho com óbito deve se restringir a apenas a uma única demanda e limitada à percepção de indenização ao círculo familiar estrito da vítima (viúva e filhos), sem possibilidade de ajuizamento de sucessivas ações, por inúmeras pessoas, ligadas da mesma forma ao vínculo afetivo do ofendido, por criar instabilidade jurídica, assim, realizada a conciliação, transação ou recebimento de indenização por sentença judicial, não há possibilidade de nova demanda para tentativa de

\footnotetext{
115 Art. 139. O juiz dirigirá o processo conforme as disposições deste Código, incumbindo-lhe: V - promover, a qualquer tempo, a autocomposição, preferencialmente com auxílio de conciliadores e mediadores judiciais; Art. 764 - Os dissídios individuais ou coletivos submetidos à apreciação da Justiça do Trabalho serão sempre sujeitos à conciliação.
} 
recebimento de nova indenização, mesmo que se trata de partes diferentes no processo, cita-se abaixo o julgado da lavra do TRT da $24^{\mathrm{a}}$ região:

ILEGITIMIDADE ATIVA. PAIS E IRMÃ. AÇ̃̃O ANTERIORMENTE PROPOSTA PELA VIÚVA E FILHOS. Admitir-se infinitas ações (pais, avós, tios, etc.) de todos os atingidos pela dor da perda, em detrimento de um único pagador, seria o mesmo que fadar as relações à insegurança jurídica, além de causar desproporcional prejuízo ao empregador. No caso, o direito à indenização por danos morais já foi exercido pelos herdeiros do empregado falecido (viúva e filhos), nos autos do proc. $\mathrm{n}^{\circ}$ 0024319-48.2016.5.24.0076. E chama a atenção o fato de que naqueles e nesses autos há identidade do procurador constituído, levando ao convencimento de que ao ajuizar a primeira ação (viúva e filhos), postulou-se o direito a todos os ofendidos. Ilegitimidade ativa reconhecida. (TRT-24 Região RO0024466-74.2016.5.24.0076, $1^{\mathrm{a}}$ Turma, Relator Marcio Vasques Thibau de Almeida, julgamento 2.8.2017, DEJT 02.10.2017).

Depreende-se desse modo, que corrente restritiva defende a inexistência de legitimidade concorrente de todos aqueles que suportam o dano decorrente do acidente de trabalho, tanto para as pretensões indenizatórias patrimoniais e extrapatrimoniais, devendo-se priorizar a legitimidade que exclui e não concorre, nos termos da ordem de vocação hereditária estabelecida pelo art. 1.829, do CC (BRASIL, 2002) ${ }^{116}$.

Assim, esta corrente teórica aduz não haver legitimidade concorrente entre todos aqueles que suportam o dano e sofrem com a perda do ente querido, vejamos decisão do colendo Tribunal Superior do Trabalho:

AGRAVO DE INSTRUMENTO EM RECURSO DE REVISTA DA
RECLAMADA. ILEGITIMIDADE ATIVA AD CAUSAM DO PAI E IRMÃO
PARA REQUERER INDENIZAÇÃO POR DANOS MORAIS EM FACE DE
INDENIZAÇÃO JÁ CONCEDIDA À VIÚVA E Ã FILHA EM OUTRA AÇÃO -
Considerada a existência de divergência jurisprudencial válida, dá-se provimento ao
agravo de instrumento. Agravo de instrumento conhecido e provido. B) RECURSO
DE REVISTA DA RECLAMADA. ILEGITIMIDADE ATIVA AD CAUSAM DO
PAI E IRMÃO PARA REQUERER INDENIZAÇÃO POR DANOS MORAIS EM
FACE DE INDENIZAÇÃO JÁ CONCEDIDA Â VIÚVA E À FILHA EM OUTRA
AÇÃO. A controvérsia recursal se resume em definir se os autores (pai e irmão do
falecido) possuem legitimidade para pleitear indenização por danos morais, tendo
em vista que a viúva e a filha do de cujos já pleitearam e receberam indenização
pelo mesmo fato em ação anteriormente ajuizada. Não há dúvida de que podem
reclamar a reparação por danos morais os herdeiros, cônjuge ou companheiro (a) e
os membros da família ligados afetivamente ao lesado. Contudo, tal questão ganha
maior relevância quando o ofendido falece, o que pode permitir o ajuizamento de
ações em cascata, afetando, sobremaneira, a segurança jurídica, mesmo após
configurada a coisa julgada e reparado o dano em outra demanda. A segurança
jurídica é um dos pilares do Estado Democrático de Direito e está intimamente
ligada ao valor de justiça. Assim, a possibilidade de ajuizamento de sucessivas
ações, por inúmeras pessoas, ligadas da mesma forma ao ofendido (vínculo afetivo),

116 Art. 1.829. A sucessão legítima defere-se na ordem seguinte: I - aos descendentes, em concorrência com o cônjuge sobrevivente, salvo se casado este com o falecido no regime da comunhão universal, ou no da separação obrigatória de bens (art. 1.640, parágrafo único); ou se, no regime da comunhão parcial, o autor da herança não houver deixado bens particulares; II - aos ascendentes, em concorrência com o cônjuge; III - ao cônjuge sobrevivente; IV - aos colaterais. 
cria instabilidade. Dessa forma, não há falar em legitimidade concorrente de todos aqueles que suportam o dano e sofrem com a perda do ente querido, mas, em respeito à segurança jurídica, bem maior a ser preservado, deve-se priorizar a legitimidade excludente, privilegiando-se as regras da ordem de vocação hereditária estabelecida pelo Código Civil. Recurso de revista conhecido e provido. C) AGRAVO DE INSTRUMENTO EM RECURSO DE REVISTA DOS $3^{\circ}$ E $4^{\circ}$ RECLAMANTES. Prejudicada a análise do recurso tendo em vista o provimento do recurso de revista da reclamada. (TST-ARR- 1685-14.2010.5.04.0662, $8^{\mathrm{a}}$ Turma, Relatora Min. Dora Maria da Costa, julgt ${ }^{\circ}$ 5.6.2013, DEJT 14.6.2013).

Mormente, para uma primeira corrente teórica, será possível a propositura de ação de indenização por danos morais por qualquer pessoa ligada ao círculo afetivo do de cujus, sob a alegação de lesão aos seus direitos de personalidade, ou seja, o direito de ação será de todos aqueles que mantinham de certa forma laços de afeto com o falecido. Já para uma segunda corrente que vem prevalecendo atualmente, a legitimidade se restringe ao cônjuge sobrevivente e aos filhos menores da vítima, estendendo-se aos demais na ausência destes, porém, com um detalhe importante, limitando-se a apenas um processo judicial, ou seja, ajuizada a demanda por uma parcela dos legitimados, já estará incluída a quantia para reparação por danos sofridos a todos os membros da família.

Cita-se que a hipótese apresentada referente à possibilidade de percepção de indenização por danos morais para todos os membros adstritos ao núcleo familiar do empregado é positiva juridicamente, conforme exposto pelas correntes teóricas citadas acima, podendo coexistir várias demandas judiciais oriundas do mesmo fato, porém, conforme uma segunda corrente que vem prevalecendo atualmente, a legitimidade se restringe ao cônjuge sobrevivente e aos filhos menores da vítima, estendendo-se aos demais na ausência destes.

Esta posição mais restritiva visa evitar sucessivos processos (pais, irmãos, avós, tios, sobrinhos, etc.), todos que de alguma forma são atingidos pelo sofrimento da perda, em sacrifício de um único pagador, causando desproporcional prejuízo ao empregador e insegurança jurídica. Por outro lado, atingirá o direito fundamental de ação destes que poderão reclamar em juízo acerca do fato, já que o processo judicial será extinto sem julgamento do mérito por falta de legitimidade ativa, prejudicando o direito subjetivo de percepção de indenização por conciliação, transação ou sentença judicial.

\section{CONSIDERAÇÕES FINAIS}

Através da análise dos inúmeros dispositivos legais e correntes teóricas acerca do direito subjetivo de indenização por danos morais decorrentes de acidente de trabalho, notou- 
se que qualquer pessoa ligada ao vínculo afetivo da vítima está apta a pleitear em juízo, reparação monetária pela dor oriunda da perda de um ente querido, nos termos do art. $5, \mathrm{~V}$ e X, da CF (BRASIL, 1988).

No entanto, inimaginável supor que cada um dos conhecidos da vítima, aí se incluindo, por óbvio, os pais, avós, tios, irmãos, sobrinhos, primos, pudessem acionar o Judiciário buscando do empregador a mesma indenização financeira pela dor sentida com a morte do ex-empregado, tratando-se de legitimidade ordinária.

Nesse contexto, se já buscaram idêntica indenização por dano moral, com o pagamento efetuado por meio de conciliação, transação e sentença judicial, entende-se que no montante já se encontrava incluída a quantia para reparação por danos sofridos a todos os membros da família e pessoas queridas, em que pese haver corrente teórica em contrário, existem entendimentos diversos que priorizam o direito subjetivo de ação indenizatória, contudo, a mesma vem sendo rechaçada pelo judiciário por criar certa insegurança jurídica, além de causar desproporcional prejuízo ao empregador.

Desse modo, o exercício do direito de ação de indenização por danos morais no âmbito dos processos judiciais do trabalho, bem como, acerca dos mecanismos judiciais de solução de conflitos nos dissídios individuais trabalhistas está em confronto com o interesse processual dos familiares da vítima de acidente de trabalho, que são motivados pela dor da perda do ente querido, diante da existência legal do direito subjetivo ofendido.

Portanto, para uma primeira corrente teórica, será possível a propositura de ação de indenização por danos morais por qualquer pessoa ligada ao círculo afetivo do de cujus, sob a alegação de lesão aos seus direitos de personalidade, ou seja, o direito de ação será de todos aqueles que mantinham de certa forma laços de afeto com o falecido. Já para uma segunda corrente que vem prevalecendo atualmente, a legitimidade se restringe ao cônjuge sobrevivente e aos filhos menores da vítima, estendendo-se aos demais na ausência destes, porém, com um detalhe importante, limitando-se a apenas um processo judicial, ou seja, ajuizada a demanda por uma parcela dos legitimados, já estará incluída a quantia para reparação por danos sofridos a todos os membros da família, quanto aos valores recebidos em transação, conciliação e execução de sentença.

Esta posição mais restritiva visa evitar sucessivos processos (pais, irmãos, avós, tios, sobrinhos, etc.), todos que de alguma forma são atingidos pelo sofrimento da perda, em sacrifício de um único devedor, causando desproporcional prejuízo ao empregador e insegurança jurídica. 
Assim, a indenização por danos morais já percebida pelos herdeiros do empregado falecido (viúva e filhos) por meio de transação, conciliação ou sentença judicial é capaz de prejudicar a abertura de nova demanda pelos demais familiares (pais e irmãos) na busca da mesma indenização, em exercício do direito de ação permitido pela Constituição Federal, sendo cada vez menor a possibilidade de percepção de indenização por danos morais em sucessivas ações, por inúmeras pessoas, ligadas da mesma forma ao vínculo afetivo do ofendido.

Dessa forma, a transação, a conciliação e a sentença judicial poderão provocar óbice ao direito de percepção de indenização por todos aqueles familiares ligados de certa forma ao vínculo afetivo do ofendido, que suportam o dano e sofrem com a perda do ente querido vitimado em acidente de trabalho diante da ordem de vocação hereditária estabelecida pelo Código Civil, em primazia da segurança jurídica evitando o desproporcional prejuízo ao empregador e a morosidade processual.

Nesta posição restritiva, sacrifica-se o direito subjetivo em detrimento de uma maior segurança jurídica nas relações trabalhistas, já que havendo várias demandas judiciais oriundas do mesmo fato, poderá acarretar certa instabilidade no Poder Judiciário, além de que a morosidade processual provoca prejuízo para ambas as partes.

Por todo o exposto, a conciliação, transação e a sentença judicial poderão provocar óbice a propositura de novas demandas judiciais indenizatórias, não pela caracterização de coisa julgada, já que não há identidade de partes, mas sim em respeito à segurança jurídica. Sem dúvida, tais mecanismos promovem a solução dos conflitos trabalhistas de forma mais célere e efetiva em termos de satisfação das partes, cabendo apenas delimitar os sujeitos desta relação e a amplitude dos efeitos desta disposição de direitos como método eficaz de pacificação social.

\section{REFERÊNCIAS}

BRASIL. Constituição da República Federativa do Brasil de 1988. Disponível em: <www.planalto.gov.br>. Acesso em: 23 mai. 2018.

BRASIL. Decreto-lei $n^{o}$ 5.452, de $1^{o}$ de maio de 1943. Consolidação das Leis do Trabalho. Diário oficial da união, 1 maio. 1943. Disponível em: <www.planalto.gov.br>. Acesso em: 24 mai. 2018. 
BRASIL. Lei $n^{\circ}$ 13.105, de 16 de março de 2015. Código de Processo Civil. Diário oficial da união, 17 março. 2015. Disponível em: <www.planalto.gov.br>. Acesso em: 03 mai. 2018.

BRASIL. Lei $n^{o}$ 10.406, de 10 de janeiro de 2002. Institui o Código Civil. Diário oficial da união, 11 janeiro. 2002. Disponível em: 〈www.planalto.gov.br〉. Acesso em: 24 mai. 2018.

BRASIL. Lei 8.213, de 24 de julho de 1991. Dispõe sobre os Planos de Benefícios da Previdência Social e dá outras providências. Diário oficial da união, 25 jul. 1991. Disponível em: 〈www.planalto.gov.br〉. Acesso em: 11 jun. 2018.

BRASIL. Decreto $n^{\circ} 7.602$, de 7 de novembro de 2011. Dispõe sobre a Política Nacional de Segurança e Saúde no Trabalho - PNSST. Diário oficial da união, 08 nov. 2011. Disponível em: <www.planalto.gov.br>. Acesso em: 11 abr. 2018.

CANOTILHO, José Joaquim Gomes. Direito Constitucional e Teoria da Constituição. 7. ed. Coimbra: Almedina, 2003.

CALMON. Petrônio. Fundamentos da mediação e de Conciliação. Rio de Janeiro: Editora Forense, 2008.

CALMON DE PASSOS, José Joaquim. Comentários ao Código de Processo Civil. 8. Ed. Rio de Janeiro: Forense, 2001.

CAVAlIERI FILHO, Sérgio. Programa de responsabilidade civil. 10. Ed. São Paulo: Atlas, 2012.

CASSAR, Vólia Bomfim. Direito do trabalho. 9. ed. São Paulo: Método, 2014. ISBN 97885-309-5497-0, e-book.

CASSETTARI, Christiano. Elementos de direito civil. São Paulo: Saraiva, 2011.

DELGADO, Mauricio Godinho; DELGADO, Gabriela Neves. Constituição da República e Direitos Fundamentais: Dignidade da pessoa humana, justiça social e direito do trabalho. 3. Ed. São Paulo: LTR, 2015.

DALLEGRAVE NETO, José Affonso. Responsabilidade civil no direito do trabalho. 5. Ed. São Paulo: LTR, 2014. 
DIAS, José de Aguiar. Da responsabilidade civil. $3^{\text {a }}$ ed. Rio de Janeiro: Forense, 1954.

DINAMARCO, Cândido Rangel. Instituições de direito processual civil. São Paulo: Malheiros, 2001.

FARIAS, James Magno A. Jurisdição e mediação: a atuação da justiça do trabalho para garantir a proteção dos direitos laborais e possibilidade de mediação trabalhista no Brasil. Revista do TST, ano 81, n. 2, 2015.

KANT, Immanuel. Fundamentação da metafísica dos costumes. Tradução Paulo Quintela. Lisboa: Edições 70, 2005.

MARTINS, Sergio Pinto. Direito Processual do Trabalho. 40ª ed. São Paulo: Saraiva, 2018.

OLIVEIRA, Sebastião Geraldo de. Proteção jurídica à saúde do trabalhador. São Paulo: LTr, 1988

. Indenizações por acidente do trabalho ou doença ocupacional. 7. Ed. São Paulo: LTR, 2013.

PINTO JUNIOR, Amaury Rodrigues. A quantificação do dano: acidente do trabalho e doenças ocupacionais. São Paulo: LTR, 2016.

SARLET, Ingo Wolfgang. Dignidade da pessoa humana e direitos fundamentais na Constituição Federal de 1988. 4. ed. Porto Alegre: Livraria do Advogado, 2006.

SENA, Adriana Goulart de. Juízo conciliatório trabalhista. Belo Horizonte: Revista do Tribunal Regional do Trabalho da 3ª Região, v. 45, n. 75, p. 139-161, jan/jun. 2007.

SEVERINO, Antônio Joaquim. Metodologia do trabalho científico. $24^{\text {a }}$ ed. São Paulo: Cortez, 2016.

SOUTO MAIOR, Jorge Luiz. Relação entre o processo civil e o processo do trabalho. O novo Código de Processo Civil e seus reflexos no processo do trabalho. Salvador: JusPodivm, 2015.

STOCO, Rui. Tratado de Responsabilidade civil: doutrina e jurisprudência. 7. ed. São Paulo: Revista dos Tribunais, 2007. 
SUSSEKIND, Arnaldo. Instituições de direito do trabalho. 19ª ed. São Paulo: LTr, 2000.

WENCESLAU, M. E.; SANTOS, D. O. A globalização do trabalho e os movimentos sindicalistas frente ao MERCOSUL: prospecções e projeções. Disponível em: <http://www.seer.ufv.br/seer/revdireito/index.php/RevistaDireito-UFV/article/view/420> Acesso em: 12 nov. 2017. Revista de direito, v. 8, n. 2, p. 151-181, 2016.

\title{
FUNDAMENTAL RIGHTS OF WORKERS: SUBJECTIVE RIGHT OF INDEMNIFICATION FOR MORAL DAMAGES TO FAMILIES OF VICTIM OF WORK ACCIDENTS
}

\begin{abstract}
The article explores the legal aspects for the perception of indemnity due to accident of the work with death. The objective is to map and analyze whether the compensation for moral damages already perceived by the heirs of the deceased employee (widow and children) by means of a transaction, conciliation or judicial sentence creates an obstacle to the opening of a new demand by the other relatives (parents and siblings) of the same indemnity, in exercise of the right of access to justice allowed by the Federal Constitution of 1988. As for the research problem, it will be to describe the possibility of receiving compensation for moral damages in successive actions, by numerous persons, affection of the offended by means of new transaction, conciliation or judicial sentence? The hypothesis presented refers to the possibility of obtaining compensation for moral damages for all members attached to the employee's strict family nucleus, and there may coexist several lawsuits arising from the same fact. The scientific research will have methodology as follows: pure, qualitative, exploratory, descriptive and bibliographical, with the analysis of legislation, scientific articles, legal works and material made available on the Internet.
\end{abstract}

Keywords: Access to justice. Employer responsibility. Accidents at work. Legal means of resolving labor disputes. Indemnity for moral damages. 